\title{
INFLUENCES OF THE PSYCHIATRIC REFORM IN NURSING CARE AT THE CASA DE SAÚDE ESPERANÇA, IN JUIZ DE FORA, MINAS GERAIS, BRAZIL
} (1994-1998)

\author{
Ângela Aparecida Peters Rodrigues ${ }^{1}$, Maria Lelita Xavier², Mariangela Aparecida Gonçalves de Figueiredo², \\ Antonio José de Almeida Filho ${ }^{4}$, Maria Angélica Almeida Peres ${ }^{5}$
}

\footnotetext{
${ }^{1}$ M.Sc. in Nursing. Escola de Enfermagem Anna Nery (EEAN) - Universidade Federal do Rio de Janeiro (UFRJ). Rio de Janeiro, Rio de Janeiro, Brazil. E-mail: angelaprodrigues@yahoo.com.br

2 Ph.D. in Nursing. Professor, Faculdade de Enfermagem, Universidade do Estado do Rio de Janeiro. Rio de Janeiro, Rio de Janeiro, Brazil. E-mail: lely108@hotmail.com

${ }^{3}$ Ph.D. in Nursing. Nurse, Hospital Universitário, Universidade Federal de Juiz de Fora. Juiz de Fora, Minas Gerais, Brazil. E-mail: mary. hu@ig.com.br

${ }^{4}$ Ph.D. in Nursing. Professor, EEAN/UFRJ. Rio de Janeiro, Rio de Janeiro, Brazil. E-mail: ajafilhos@gmail.com

${ }^{5}$ Ph.D. in Nursing. Professor, EEAN/UFRJ. Rio de Janeiro, Rio de Janeiro, Brazil. E-mail: angelica.ufrj@uol.com.br
}

\begin{abstract}
The aim of this socio-historical study was to describe the insertion process of nurses and to analyze the reformulation strategies of nursing care at the Casa de Saúde Esperança from 1994 to 1998. Historical sources, written and oral documents, were analyzed based on Michel Foucault's concept of power/knowledge. The results showed that, after nearly three decades of working in the absence of or with only one nurse, the Casa de Saúde Esperança hired four nurses, in order to meet the legal requirements of operation. To expand their power/knowledge in nursing, the nurses promoted meetings and trainings with the team. It was concluded that the strategies used produced effects such as: greater recognition of the power/knowledge in nursing; practical knowledge giving way to scientific knowledge; development of a more humanized care; and accreditation of the institution in psychiatry IV, which, by psychiatric hospitals' classification, allowed its operation in partnership with the Unified Health System.
\end{abstract}

DESCRIPTORS: Nursing history. Psychiatric nursing. Psychiatric aides. Nursing care.

\section{INFLUÊNCIAS DA REFORMA PSIQUIÁTRICA NO CUIDADO DE ENFERMAGEM NA CASA DE SAÚDE ESPERANÇA EM JUIZ DE FORA, MINAS GERAIS, BRASIL (1994-1998)}

RESUMO: Estudo sócio-histórico cujos objetivos são o de descrever o processo de inserção de enfermeiros e analisar as estratégias de reformulação do cuidado de enfermagem na Casa de Saúde Esperança, no período de 1994 a 1998. Fontes históricas, documentos escritos e orais foram analisados com base no conceito de saber/poder de Michel Foucault. Os resultados mostraram que, após quase três décadas funcionando na ausência ou com apenas uma enfermeira, a Casa de Saúde Esperança contratou quatro enfermeiros visando atender exigências legais de funcionamento. Para ampliar o saber/poder da enfermagem, os enfermeiros promoveram reuniões e capacitações junto à equipe. Concluímos que as estratégias utilizadas produziram efeitos como: maior reconhecimento do saber/poder da enfermagem, o saber prático deu lugar ao saber científico; desenvolvimento de uma assistência mais humanizada; credenciamento da instituição em psiquiatria IV, que, pela classificação dos hospitais psiquiátricos, permite seu funcionamento em convênio com o Sistema Único de Saúde. DESCRITORES: História da enfermagem. Enfermagem psiquiátrica. Auxiliares de psiquiatria. Cuidados de enfermagem.

\section{INFLUENCIAS DE LA REFORMA SIQUIÁTRICA EN EL CUIDADO DE ENFERMERÍA EN LA CASA DE SALUD ESPERANZA EN JUIZ DE FORA/ MINAS GERAIS/BRASIL (1994-1998)}

RESUMEN: Estudio socio histórico cuyo objetivos son describir el proceso de inserción de enfermeros y analizar las estrategias de reformulación del cuidado de enfermería en Casa de Saúde Esperança, entre los años 1994 y 1998. Fuentes históricas, documentos escritos y orales, analizados basándose en el concepto de saber/poder de Michel Foucault. Los resultados mostraron que después de casi tres décadas de funcionamento con ausencia o con solo una enfermera, la Casa de Saúde Esperança contrató cuatro enfermeros para atender exigencias legales de funcionamiento. Para ampliar el saber/poder de la enfermería, promovieron reuniones y capacitaciones junto al equipo. Las estrategias utilizadas produjeron efectos como: mayor reconocimiento del saber/poder de enfermería, en la que un saber práctico dio lugar a un saber científico; desarrollo de un modelo asistencial más humanizado; acreditación de la institución en siquiatría IV, por esa clasificación los hospitales siquiátricos tenían permiso para trabajar en convenio con el Sistema único de salud.

DESCRIPTORES: Historia de la enfermería. Enfermería psiquiátrica. Auxiliares de psiquiatría. Atención de enfermería. 


\section{INTRODUCTION}

Founded in the late 1930s in the city of Juiz de Fora, Minas Gerais, Brazil, to treat patients of both sexes with mental disorders, the Casa de Saúde Esperança (CSE) was marked, until the 1990s, by an assistance guided exclusively by admission and traditional psychiatric treatment, initially conducted by a team consisting of doctors and nursing attendants. ${ }^{1}$ The predominant treatment model of traditional psychiatry, in the decades from 1930 to 1990, was characterized by alignment to the clinical and biological model, having the psychiatric hospital as its treatment center. In this model, care had no rehabilitation pretensions; it just kept individuals with mental disorders socially isolated for long periods of hospitalization, which allowed nursing care to be performed by unqualified personnel. ${ }^{1}$

This study's research problem is the fact that, for over three decades of operation of the CSE, the nursing professional was absent, or was there for a very short time, due to the difficulty for these professionals to remain in the institution and to their leaders' disinterest in hiring graduates, whose salaries would burden the institutional budget.

The historical, political, and social context in the last decades of the twentieth century is complex when it comes to mental health policies in Brazil. The Unified Health System (SUS), established by Federal Law 8.080/90, invested in the advancement of the psychiatric reform movement, which was being organized since the 1970s and had been established by Project No. 3.657, also known as the Antimanicomial Law Project, presented to the National Congress in 1989. Since then, processes such as dehospitalization and deinstitutionalization were encouraged by other legislations that became effective in 1990 and 2000. The hospital also produced new care devices for mental health that were integrated into the SUS primary care network. These projects were responsible for developing strategies to contemplate welfare measures for the humanization of care and the preservation of the citizenship rights of people with mental disorders. ${ }^{2}$

Although new legislation underpins the foundations of the psychiatric reform, hospital institutions maintained their operation, and the transition from the traditional model to the psychosocial model occurred and is still occurring, slowly. In Minas
Gerais, there was an axis known as the "madness corridor," formed by the cities of Belo Horizonte, Barbacena, and Juiz de Fora which, together, harbored $80 \%$ of psychiatric state beds. This inertia was the result of political and economic interests that involved the release processes of hospital beds, the creation of new care facilities in mental health, and closing institutions. ${ }^{2}$

It was only in early 1990 that the CSE hired a nurse to act as technically responsible (TR). Some difficulties hindered the improvements to be implemented, such as: nursing staff's resistance to recognize the authority; absence of supervising nurses in shifts; low educational level of nursing attendants; and the traditional psychiatric model in force. This nurse worked towards the hiring of other nurses, which happened in 1994, after an inspection of the Regional Nursing Council required the CSE to comply with the Law of Professional Nursing Practice. ${ }^{3}$

The hiring of nurses by the CSE was related to various social, political, and economic factors. The creation of laws that supported the new policies on mental health modified the functioning and organization of psychiatric institutions, causing a movement of these institutions in search of the socalled accreditation, which would allow operation and partnership with the SUS and bring financial benefits to these establishments.

Therefore, the entry of nurses into the CSE came to provide the institution with adequacy in new psychiatric treatment concepts which, in the growing movement of psychiatric care reform in Brazil, focused on rehabilitation in order to avoid patients' staying in the psychiatric institution for hospitalization and to assist in the integration of the mentally ill into society. In the 1990s, the ideology of community care gained strength while maintaining the issue of rehabilitation, including the goal of bringing independence, self-management capacity, and better quality of life to the individual. ${ }^{4}$

Given the above, the object of this study is the development of psychiatric nursing in the CSE, in Juiz de Fora, in the period from 1994 to 1998, marking, respectively, the year when four nurses were hired by the CSE and the year of reformulation of nursing care through the implementation of rules and routines to be followed by the team. The objectives are to describe the nurses' insertion process 
and analyze their strategies to reshape the nursing care in the CSE during this period.

It is believed that there is a historical relevance to registering the existence of an institution that still maintained the traditional psychiatric model in the 1990s and the role of the nursing staff in the transformation of this model, in order to better reflect on the development of the psychiatric reform in Brazil. The study is justified by the need to understand the history of institutions in different regions and historical periods, because it allows studying the practice of psychiatric nursing in the public and private healthcare network, in the context of the psychiatric reform movement. Therefore, the CSE is taken as reference: a referral psychiatric hospital in the city of Juiz de Fora.

\section{METHOD}

This is a qualitative socio-historical study whose primary sources were written documents found in the collection of the CSE and oral reports produced in the period from August to December 2011, through interviews with 11 professionals who worked in the CSE. Secondary sources were books and articles. For the production of oral documents, a thematic oral history was used, known as a process of enlarging the possibility of using sources for factual writing, in addition to bringing historians an instrument to deal with subjectivity. ${ }^{5}$

The project that gave rise to this study was approved by the Research Ethics Committee of the Escola de Enfermagem Anna Nery, Hospitla Escola São Francisco de Assis, Universidade Federal do Rio de Janeiro, in 2011 (protocol 040/2011).

The procedures for the production of oral reference were: prior contact with every possible collaborator by e-mail or phone call, inviting him/her to participate in the survey; scheduling of place and date, chosen by the collaborators, for the interviews, which were recorded on an $\mathrm{mp} 3$ device and lasted about 40 minutes; transcription of the interviews; presentation of the transcript to the collaborators for agreement on its use in the research and divulgation through articles and scientific papers. It should be noted that these steps follow the ethical recommendations of the Conselho Nacional de Saúde Resolution 466/12.

Of the 11 professionals who collaborated in the production of oral sources for this study, five are mentioned in this article: two nurses and three doctors, all graduates in the city of Juiz de Fora. Most of them had graduated over five years previously when they began working in the CSE. The dwell time in the institution ranged from two to 13 years.

The collaborators are cited in the text with the initial corresponding to their profession Nurse $(\mathrm{N})$; Doctor (D) and a number corresponding to the sequential order of the interview, in order to ensure the confidentiality of the information. The theoretical basis of the documentary corpus analysis was the concept of Michel Foucault, present in the prescribed power/knowledge, and in accordance with the historical method, considering the context in which the documents were produced and their external and internal criticism. In this process, repeated readings were taken with a view toward identifying elements of analysis to be presented as results. ${ }^{5}$ After these procedures, the results were arranged in chronological order and theme, then they were contextualized, coming to the following agenda topics: hiring of nurses by the CSE and the inclusion of new knowledge in the nursing team; reorganization of the disciplinary space of the CSE; the transformations of the healthcare space; and the accreditation of the CSE in Psychiatry IV.

\section{RESULTS AND DISCUSSION}

\section{The hiring of nurses by the CSE and the inclusion of new knowledge in the nursing team}

In the early 1990s, the Brazilian Psychiatric Reform had already passed laws that required changes in hospital models. In addition, the development of nursing approved Resolution No. 146 of 1992, which standardized the presence of nurses in all healthcare facilities nationwide where nursing actions were developed. Therefore, the nurse was already recognized as essential to the functioning of health institutions and to the new configuration of psychiatric care. The professional's participation was counted on for the reformulation of the principles of care, the redefinition of assistance priorities, and for the devices that would allow the gradual extinction of the asylum service.

In Minas Gerais in the 1990s, the Mental Health State Coordination showed that psychiatric institutions were experiencing a state of precariousness regarding physical structure and assistance 
provided, and initiated a process of change, creating mental health policies for issues such as: infrastructure of psychiatric institutions and quality of care, considering the relationship between health staff/ number of inpatients. ${ }^{6}$

The reorganization of the psychiatric care model expanded the nursing field of action that needed to emerge from the old routine of primary care and monitoring of hospitalized patients with mental disorders to also tend to the rehabilitation and social reintegration of these individuals, making it a more complex and comprehensive care, thus consolidating what came to be called mental health. However, in the CSE, still in the 1990s, the disciplinary model necessary for the hierarchical surveillance was mostly comprised of nursing aides at the base and the medical director at the top of the professional pyramid which, as a rigid disciplinary system, did not work, because it lacked a portal and a submission to the people a pyramid looks after. In the CSE, the medical director did not visit the wards regularly, reducing the presence of the hierarchical look at the nursing team.

The changes in the disciplinary area of the CSE were influenced by the expansion of staff, which became well characterized in 1994, when the only nurse responsible for nursing services asked the management of the institution to hire other nurses in order to assemble the teams on duty with their presence, as required by the Law of Professional Practice of Nursing. ${ }^{7}$ For the CSE, hiring this professional represented a strategy that would reorganize the psychiatric care in the institution, by involving them in the reformulation of the principles of care and redefinition of assistance priorities and devices that would allow the gradual extinction of the asylum service, once the CSE sought to meet the legal requirements to operate. With the remodeling of psychiatric care in the 1990s, nurses were seeking new possibilities of care by giving voice to the subjects, focusing on them, their history, and their subjectivity, no longer just the symptoms. ${ }^{8}$

Thus, the nurse that suggested the hiring was authorized by the direction of the CSE to select four nurses to compose the institution's staff. The choice of the professionals to be hired occurred directly by the nurse, because the institution had no selection and recruitment department: [...] No selection process was open; it was by indication. I received the curriculuns, did the interviews and hired whoever seemed to have a more appropriate profile to deal with this clientele. Two of them had no experience in psychiatry and the others were already placed in institutions with their own characteristics. It is a very difficult area to find this professional; we have no capable professionals within psychiatry. We do find, most of the time, those who merely have worked in a psychiatric hospital, but don't have any of the qualities that must characterize an individual to work in mental health [...] (N1).

The nurse's analysis shows the influence of the history of psychiatry in psychiatric nursing care and its slow pace of development. Psychiatric nursing, in the early twentieth century, was surrounded by prejudices and involved overcrowding, poor conditions in institutions, and stereotypes about mental patients. In addition, low wages led to the devaluation of nursing professionals working in psychiatry which, in a way, until today interferes negatively in the choice of this area of expertise and specialization, although there is academic and professional recognition of psychiatric nursing. ${ }^{9}$

Despite the lack of availability of nurses with experience in the area of psychiatry in Juiz de Fora, there was concern in selecting professionals able to provide quality care in the CSE: [...] During the interview, I asked them to talk a little bit about their professional experience and their expectations. I tried to realize their involvement, their knowledge, attitude, and interest [...] (N1).

The nurse also reported that, during the selection of new nurses, she sought their affinities with the psychiatric nursing: [...] during the interview, I tried to analyze, in the candidates attracted by the recruitment, professional, and personal aspects, with a view to suitability for the job [...] (N1).

The standard or criterion for selection should be obtained from the features of the position to be filled. Thus, the basis for selection is the acquisition of information for the position in order to facilitate comparison between the established profile and the candidate's profile, for instance: technical and scientific knowledge; professional experience; commitment to the institution and management; attendance; attitude; punctuality; and ethics; aiming to reach the expected results and the integration of the new professional to the work group. ${ }^{10}$

Regarding the profile of the nurses, one of them worked in urgency and emergency care in a general hospital, where he had contact with psychiatric patients; two had no previous experience in psychiatry; one had previously worked in the CSE 
and was returning. They were all aged between 25 and 35 and had graduated from the Federal University of Juiz de Fora; there were three men and one woman. One of the candidates had also graduated in music and none of them was specialized in mental health. The TR nurse who interviewed the candidates had graduated from the Hermantina Beraldo Nursing School in 1975 and was a specialist in obstetric nursing. ${ }^{11}$

The nurses were hired according to the Consolidation of Labor Laws, and the established work schedule was during night shifts 12 for 36 hours, with the day shift from 7 a.m. to 7 p.m. and the night shift from 7 p.m. to 7 a.m. After this hiring, the nurses' presence on each shift team was guaranteed, as they were responsible for the supervision of two male wards and three female wards. The work was in scheduled scales, in addition to the nurse responsible for the nursing service that was in the institution. ${ }^{11}$

In this way, the CSE's nursing staff was better scrutinized, which led to reorganization by the entry of a new member in the disciplinary pyramid, that was now hierarchically composed, from bottom to top, by attendants, nursing assistants, and technicians, nurses, physicians, and TR chief nursing. The arrival of these new professionals inserted, in the space of the CSE, a group with specific knowledge by whom attendants, nursing assistants and technicians began to be supervised, which represented a break in the old model and the beginning of a takeover in the management of nursing services by the newly hired nurses.

\section{Reorganization of the disciplinary space of the CSE}

The moment that followed the hiring of nurses was marked by conflict, because the nursing attendants ignored the presence of nurses and went directly to the hospital's medical director when faced with a problem that they did not feel able to solve. This situation was illustrated by respondents when they pointed out the resistance by nursing assistants and attendants in relation to the nurse's presence in the institution: [...] They would say: "What is this person doing here? I know how to do it; what is she here to teach me?" Because, for them, the knowledge they had was enough. But it was not, and they did not understand that. It took a while until they recognized it. [...] (D2).
[...] In general, the relationship with the team was good. However, some employees did not accept the presence of the nurse because, at that time, they did not have a good notion of hierarchy within the hospital. They were used to deciding everything, so that notion of hierarchy was not well developed. They thought they could make decisions on their own, especially when we weren't there [...] (N1).

The questioning of the nurse's role, on the one hand, reflects rejection of their presence in the team and, on the other, shows that the attendants felt they possessed a knowledge structured in everyday practice, and that it does not cease being knowledge because of it. Formal knowledge, socially recognized, was not clearly a need for these professionals, because what they knew allowed them to exercise power in the wards of the CSE. But this was only possible while the nurse's presence was not acknowledged, with this recognized formal knowledge that could impose and transform the practice hitherto exercised. ${ }^{12}$

An administrative and healthcare transformation began in the CSE, influenced by a new power/ knowledge brought by nurses and by the exercise of the hierarchical supervision inherent to the nursing supervision and to care planning, incumbent on the nurse.

The nursing care in the CSE was marked by an indirect supervision and, with the arrival of the nurses, began a process of organization and redistribution of activities of attendants, nursing assistants, and technicians. Inevitably, conflicts arose because, until the arrival of the nurses, the doctor or the administrator was the reference for the team, and most of the time they made the decisions themselves: [...] The attendants were the ones who made decisions about the medications, then communicated afterwards, after they had already done a lot of things. There was a lot of resistance [...] (D3).

It was observed that the absence of continued vigilance gave power to the nursing attendants, who took actions without prescription and without consulting the doctor. This was possible because, in disciplinary institutions, the power is exercised within a network and, in the case of the CSE, in the absence of nurses, this power was incorporated by those remaining in the institution, in everyday practice, and developed a knowledge able to solve the problems they experienced without immediately consulting a legally competent professional. 
One of the biggest obstacles faced by the newly hired nurses was related to the recognition of the professional hierarchy, that is, respect for the code of ethics of the nursing profession, because the direct supervision of the team was the nurse's liability. The nurse should guide the nursing staff to ensure the provision of a safe assistance, appropriate to the duties of each member of the nursing staff. ${ }^{13}$

The lack of training of nursing attendants and the years working in the CSE caused them and the few nursing assistants and technicians to refuse to recognize nurses as part of their team, an attitude justified by aspects such as unfamiliarity with the law of the nursing profession and having worked for many years under the supervision of the doctor, who also supported them, because there were no direct questioning about their conduct, not even about medicating the patients and communicating with the doctor afterwards. Therefore, it was expected that this sudden transformation of roles, functions, and skills caused discomfort within the nursing team.

A third aspect is related to the trajectory of psychiatric nursing care, which kept many professionals still clinging to old and bad habits, acquired during years of practice based on the biomedical model and a little nursing that was not at all autonomous. ${ }^{13}$ Until then, the CSE had never had regulation of the nursing team in their organizational and care structure, even though there was a law in place since the 1980s. This was the result of an administrative policy aimed at profit through hiring less qualified professionals, even if it meant low quality care. On the other hand, the nursing staff recognized the hierarchy in the figure of the medical director or manager, with whom they were already familiar and with whom it was easier to get decisions in their favor, due to these professionals' distance from the everyday practice in the wards, the space where the nursing staff exercised their power/knowledge.

As a strategy, the group of nurses sought a more effective communication between the different levels, for the construction of a harmonized work aimed at improving the procedures, putting the patients with mental disorders in the institution's focus of attention. The resistance and nonadherence of some attendants, nursing assistants, and technicians to comply with the orders and the non-acceptance of the proposed changes led to the dismissing of some of these professionals from the CSE, mainly nursing attendants who did not accept the professionalization imposed by Federal Law No. 7.498/86 and required by nurses. This law recognized the existence of unqualified nursing staff exercising the profession, but granted a period of ten years for them to be professionalized and become, at least, nursing assistants. ${ }^{14}$

For Foucault, these resistance points are present throughout the power network. Thus, the nurse's presence imposes disciplinary mechanisms that show a specific way of punishing; that is, individuals are evaluated and individualized. ${ }^{15}$

[...] Part of the team of attendants did not adhere to the changes. So it was very difficult to work with them, especially ancient attendants, who were there for about 20, 30 or more years, and were not used to having the leadership of the nurse. When we got there and started to draw up rules and routines for them to comply, they started to complain, resist. But they were annulled by the others who participated with us. It turned out that the new employees, who were hired, were nullifying these ancient ones until they lost strength [...] (N4).

The work of nurses turned to the disciplining of the spaces; of the nursing; of the patients with mental disorders and of the hospital itself. They started to value the standards of conduct, common sense, good treatment for people with mental disorders, also referring to the cleanliness of the environment, in addition to the food. In this context, the power is a domain of the nurse, holder of an authorized knowledge and responsible for organizing the hospital nursing staff, dominating the whole process and reproducing, to some extent, social class relationships. Establishing power relations with the attendants, nursing assistants, and other professionals for their own reproduction leads to a new field of knowledge, which, reciprocally, constitutes new power relations. ${ }^{14}$ To develop this process, the nurse used instruments such as: observation; data collection; planning; development; evaluation; technical procedures; and the relationship and communication with the patients with mental disorders, nurses, and other professionals. ${ }^{16}$

Thereby, the nursing care, which was initially carried out in an integrated manner by one person (even if not professionalized), became fragmented into different techniques or tasks, enabling the development of the so-called functional nursing practice, which is aimed at saving time and increase agility in the execution of the service. Within this 
system, the care to be provided to people with mental disorders is distributed among the members of the nursing team that, supposedly, have the technical competence to run it, because the tasks are divided by level of complexity such that the same person is attended by many members of the nursing staff. ${ }^{17}$

These forms of movement of the nursing knowledge, formed by the knowledge of the nurse, the nursing attendant, assistant and technician, classified as peripheral knowledge, lead us to understand that "[...] the hospital is not only a healing machine, but also an instrument of production, accumulation and transmission of knowledge that ensures the exercise of 'power'."15:162 In search of a better strategy and performance of the proposed activities, the alternative used by nurses made reference to a technical articulation of power, organization, and control of time and activities, and these exercises were aimed at the training and docilization of the bodies. "[...] A body that can be subjected, transformed and improved is docile." $15: 118$

\section{The transformations of the healthcare space and the accreditation of the CSE in Psychiatry IV}

Inserted in this context, the Psychiatric Reform movement required a modern, qualified, and dynamic nursing, with new practices and concepts, instruments of production, solidarity, social exchanges, and professionalism to deal with the madness and suffering, so that the mental patients were respected as human beings, possessed of rights and duties. Given this reality, nurses and other members of the nursing staff would have to be professionals able to fully meet and, whenever necessary, encourage the patient in the intricacy of human relationships. ${ }^{3}$

Among the changes that occurred in nursing care in this period was the implementation of the nursing process (NP), in compliance with the law of professional nursing practice*, whose inclusion became a strategy in the organization of nursing care in institutions, thus meeting one of the requirements for the accreditation in Psychiatry IV. On the implementation of the NP, one respondent commented: [...] In the admission, the nurse consulted, prescribed nursing care [...] because we didn't have that much care here. That was very important, even to show that hospital psychiatric care is possible. What we do not admit is asylum [...] the focus became the patient, not the disease [...] (D2).

Motivated by the authority that was incumbent to nurses, trainings in this period were conducted for how to hold dressings in patients with pressure ulcers; trainings on antibiotic therapy, immunization, and other various courses; and trainings with the whole team: [...] Many courses were conducted: first aid; conduct on a heart arrest; the role of nursing assistants and nurses; what the nursing team needs to do when intubating a patient, because the doctor doesn't do everything and needs someone to assist him; measuring blood glucose levels; how to use the new devices arriving to the institution; simple things, butvery important for the team. But all this can only be done with the hiring of nurses in greater numbers, because when there was just one, you couldn't expect him to do that, because he wouldn't be able to [...] he already had many bureaucratic things to do [...] (D2).

In order for treatment of patients with mental disorders to be more humane, the CSE began to open the hospital during new visiting hours, because some patients were not visited due to driving difficulties on Sundays:

[...] We opened the hospital for more visits because some families lived out of town and it was more difficult to come here on Sundays. There were fewer bus schedules; the visitors ended up delaying and couldn't make it to the hospital. At first, we opened for visitors every day of the week, and then we observed that it was demanding too much time from the professionals, who were giving assistance to family members, relatives of patients. So we decided to open for visitors only on Thursdays and Sundays. [...] (D1).

The participation and inclusion of the family in the treatment and monitoring of patients with mental disorders was also part of the humanization process. Recognizing the family as a care unit, inserting it into the therapeutic schedule of mental health services, making it an active agent of participation or transformation, and deconstructing a model of intervention entrenched in the social imagination is, still today, a challenge for health professionals. ${ }^{17}$

* Law 7498 of 25 June 1986. Provides for the regulation of nursing practice. Provides in Article 11, as exclusive nursing activities the nursing consultation; prescription nursing care; direct nursing care to critically ill patients with lrisk of death; more complex nursing care and requiring scientific knowledge base and ability to make immediate decisions. 
In this process occurred the extent of nursing care to family members of patients admitted to the CSE, through meetings and during visits to the inmates. Family members began to receive verbal and written instructions, were encouraged to participate more actively in treatment and decision-making processes because they were considered indispensable social actors for the effectiveness of psychiatric care and understood as a group with great potential for the hosting and resocialization of their members. ${ }^{17} \mathrm{In}$ this way, the CSE professionals sought adaptive forms of health promotion and humanization of treatment through educational and therapeutic efforts shared with the mental patients and their families, facilitating reintegration into the network of social relations.

During this transformation process, the CSE also featured a chorale of patients and staff, which was organized by a nurse who was also a musician. The chorale was, in fact, implemented, and even held recitals in the city, as described by one of the respondents: [...] We had many innovations there. This chorale was a great one. I used to go out to the streets with the patients, to sing at the mall, to sing in churches, in other psychiatric hospitals. The chorale functioned as a therapeutic approach. The doctors guided the patients to my chorale and my chorale was, in fact, a therapeutic group; there was a project, a proposal [...] so doctors directed patients to sing in the choral [...] (N4).

The period that followed the entry of the nurses was marked by a lot of productivity. The hospital bought a minibus to start the social reintegration of patients through visits and tours: [...] the bus bought by the hospital also served to take patients to the circus. Some patients, for example, were hospitalized for 15, 20 years and had never been to the circus [...] (D1).

In late February 1995, amid numerous healthcare, physical, and human resource changes, the CSE received a visit from the Monitoring Group and Hospital Psychiatric Care Evaluation (MGHPCE), formed by a multidisciplinary team and composed of members of the Mental Health State Coordination and representatives of the Federal Council of Health Professionals.

This group sets out explicit criteria for the accreditation process of hospitals in Psychiatry III and IV, so that the State was also instrumentalized in a way to regulate and supervise hospital practices by complying with the requirements established by ordinance Ministry of Health n. 224/92, which dictated the standards for hospital care/hospitals specialized in psychiatry.
In the hospitals classified in Psychiatry type III, the charge of procedures and hospitalization was significantly lower than those classified in Psychiatry IV. After verifying their regulatory compliance, a month after the visit of the MGHPCE, in March 1995, the CSE received a notice of accreditation. After this authorization, the hospital was accredited for Psychiatry IV and enabled to charge as the corresponding procedures table, which significantly increased the value of the procedures and the hospital daily.

In this sense, it is understood that the remuneration of services was linked to the quality of care provided. The concern about the actual quality, the pursuit of security and compliance with the rules in force was what generated all the motivation for changes within the CSE. The contribution and responsibility of nurses in the changes that have been implemented and gradually improved to transform the healthcare space, from the traditional isolation to a minimally social space, is immeasurable. In the years of 1996/1997 there was continuity of training with the team in order to ensure the maintenance of competence in relation to the nursing care. ${ }^{18-19}$

The year of 1998 was mainly marked by the implementation of planned routines and the elaboration of others that did not yet exist, in addition to the obligation of carrying them out in all sectors of the hospital. In the minutes, the TR nurse recorded: "[...] Plastic folders containing manuals with all standards and nursing service routines were placed in each nursing station [...]". ${ }^{11: 18-9}$ In December of the same year, the TR nurse left the CSE due to retirement, leaving a record of all of her trajectory in the relentless pursuit of a less risky and more humanized service. ${ }^{11}$ However, the professionals who stayed there had a new organization of nursing; their professionals were trained, qualified, and the standardization was established, allowing the recognition of the power/ knowledge of all nursing staff in the CSE.

\section{FINAL CONSIDERATIONS}

In the period from 1994 to 1998, the CSE invested in hiring nurses, pressured by new legal rules, which led to a broadening of the power/ knowledge of nursing, through strategies implemented by nurses to better enable the team and qualify the care provided to the mental patients admitted. The CSE sought alternatives to effect the 
new practices that met the requirements of a reality imposed by a new mental healthcare model, based on the psychosocial model.

In the context of the study, it can be concluded that changes were motivated by the challenge to achieve accreditation in Psychiatry IV, under penalty of having financial losses. There would be damage if there was no proof of compliance with the requirements imposed by the new ordinances through documentation and monitoring that would enable the CSE to continue operating. The new management practices and promotion strategies of a humanized assistance enabled the CSE to achieve accreditation in Psychiatry IV.

Thus, the nursing care was reorganized based on the legislation concerning psychiatric reform and the professional practice of nursing, which dictated the rules for the CSE to continue working within the new condition, and would enable, despite being an inpatient treatment, an assistance directed to psychosocial rehabilitation. Conditions were then created so that the nurse could work with greater autonomy, developing the psychiatric nursing practices in the institution.

\section{REFERENCES}

1. Silva RBC, Guimarães JCL. Casa de Saúde Esperança. Rev Centro de Estudo Karl Jaspers. 1980; 1(1):5-9.

2. Almeida Júnior JC. Arenas de produção de políticas públicas: a nova política nacional de saúde mental. Rev Direito GV. 2013 Jul-Dez; 9(2):659-80.

3. Rodrigues AAP. Casa de Saúde Esperança em Juiz de Fora-MG: Uma Visão Histórica Sobre a Enfermagem Psiquiátrica 1994-1998 [dissertação]. Rio de Janeiro (RJ). Universidade Federal do Rio de Janeiro, Escola de Enfermagem Anna Nery, Programa de Pós Graduação em Enfermagem; 2012.

4. VidalCEL, Bandeira M,GontijoED. Reformapsiquiátrica e serviços residenciais terapêuticos. J Bras Psiquiatr [online]. 2008 [cited 2015 Mar 02]; 57(1):. Available from: http:/ / www.scielo.br/scielo.php?script=sci_ arttext\&pid=S0047-20852008000100013

5. Santos TCF, Barreira IA, Gomes MLB, Baptista SS, Peres MAA, Almeida Filho AJ. A memória, o controle das lembranças e a pesquisa em história da enfermagem. Esc Anna Nery [online]. 2011 Jul-Set [cited 2015 Abr 02]; 15(3):616-25. Available from: http:// www.scielo.br/scielo.php?script=sci_arttext\&pi$\mathrm{d}=$ S1414-81452011000300025\&lng=en\&nrm=iso

6. Ribeiro MS, Stroppa ALPC, Salomão Neto A, Bastos MO, Costa DMT. Reforma Psiquiátrica e Atenção Primária à Saúde: O Processo de implantação do sistema municipal de saúde Mental de juiz de Fora MG. Rev APS. 2003 Jan-Jun; 6(1):19-29.

7. Conselho Federal de Enfermagem. Resolução COFEN -146/1992. [online] 1992 Jun 01 RJ [cited 2015 Mar 03]. Available from: http:/ / pr.corens.portalcofen.gov.br/ resolucao-cofen-146_2212.html

8. Oliveira RMP. Um espaço para a enfermagem psiquiátrica e de saúde mental. Esc Anna Nery. 2006 Dez; 10(4):615-7.

9. Esperidião E, Silva NS, Caixeta CC, Rodrigues J. A Enfermagem Psiquiátrica, a ABEn e o Departamento Científico de Enfermagem Psiquiátrica e Saúde Mental: avanços e desafios. Rev Bras Enferm [online]. 2013 [cited 2015 Abr 04]; 66(spe):. Available from: http:/ / www.scielo.br/scielo.php?pid=S003471672013000700022\&script=sci_arttext

10. Chiavenato I. Recursos Humanos: O Capital humano das organizações. $9^{a}$ ed. São Paulo (SP): ElsevierCampus; 2009.

11. Casa de Saúde Esperança. Ata de Reunião de Enfermeiros da CSE, Livro de Atas $\mathrm{n}^{\circ} 01$, Atas de reunião no 01 a 23, 1994 a 1998. Juiz de Fora (MG); 1998. p.1-22.

12. Foucault M. A arqueologia do saber: $8^{\mathrm{a}}$ edição: Rio de Janeiro (RJ): Forense Universitária; 2012.

13. Ribeiro JMS. Autonomia profissional dos enfermeiros. Rev Enf Ref [online]. 2011 [cited 2015 Abr 04]; ser III(5): Available from http:// www.scielo.oces.mctes.pt/scielo.php? script $=\mathrm{sci}_{-}$ arttext\&pid=S0874-02832011000300003

14. Menear M, Briand C. Implementing a continuum of evidence-based psychosocial interventions for people with severe mental illness: part 1-review of major initiatives and implementation strategies. Can J Psychiatry [online]. 2014 [cited 2015 Abr 04]; 59(4):. Available from http:/ / www.ncbi.nlm.nih.gov/pmc/ articles/PMC4079135/

15. Foucault M. Microfísica do poder. Rio de Janeiro (RJ): Graal; 2012.

16. Briand C, Menear M. Implementing a continuum of evidence-based psychosocial interventions for people with severe mental illness: part 2-review of critical implementation issues. Can J Psychiatry [online]. 2014 [cited 2015 Abr 04]; 59(4):. Available from: http:// www.ncbi.nlm.nih.gov/pmc/articles/PMC4079132/

17. Borba LO, Paes MR, Guimarães AN, Labronici LM, Maftum MA. A família e o portador de transtorno mental: dinâmica e sua relação familiar. Rev Esc Enferm USP [online] 2011 [cited 2015 Abr 04]; 45(2):442-9. Available from: http://www.scielo.br/ $\mathrm{pdf} /$ reeusp/v45n2/v45n2a19.pdf

18. Moreira LHO, Alves M. The formation of social reintegration strategies of the psychic suffering carrier: new directions for psychiatric nursing. 
Issues Ment Health Nurs [online]. 2014 Sep [cited 2015 Abr 08]; 35(9):680-8. Available from: doi: 10.3109/01612840.2014.901451

19. Peres MAA, Alencar BI. Desenvolvimento da assistência médica e de enfermagem aos doentes mentais no Brasil: os discursos fundadores do hospício. Texto Contexto Enferm [online]; 2009 [cited 2015 Abr 08] 18(4):635-42. Available from: http:// www.scielo.br/scielo.php?script=sci_ arttext\&pid=S0104-07072009000400004 